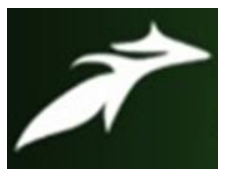

Gottipalli Jaya Pravallika et al, International Journal of Advances in Agricultural Science and Technology,

Vol.7 Issue.12, December-2020, pg. 15-20

ISSN: 2348-1358

Impact Factor: 6.057

NAAS Rating: 3.77

\title{
PERCEPTION OF FARMERS ON CLIMATE CHANGE IN CHEVELLA BLOCK, RANGAREDDY DISTRICT, TELANGANA
}

\author{
${ }^{1}$ Gottipalli Jaya Pravallika; ${ }^{2}$ Dr. Syed H Mazhar \\ ${ }^{1}$ Author, M.Sc. Agricultural Extension \\ ${ }^{2}$ Associate Professor, Dept. of Ag. Extension and Communication, \\ SHUATS, Prayagraj, 211007 \\ Email - pravallikarajesh0826@ gmail.com \\ DOI: 10.47856/ijaast.2020.v07i12.003
}

\begin{abstract}
Climate change is the burning issue of the world. Agriculture is most vulnerable to climate change. Perception of farmers is opinion of the farmers how they understand and interpret climate change. Though the Farmers' were aware about climate change, their perception totally varies from others. And farmers play major role in agriculture and it is necessary to know their perceptions. Hence, the present study was conducted in 20192020 to find out the perception of farmers on climate change in Chevella block of Rangareddy district, Telangana. Total 120 respondents from 6 villages were selected randomly. The perception results revealed that farmers' had medium level of perception and majority of farmers perceived climate change as the result of disobedience to God among all the other factors.

Keywords- Climate change, Perception of farmers, Disobedience to God
\end{abstract}

\section{INTRODUCTION}

Climate change is perhaps one of the most serious environmental issues that today's world population facing, though the issue is not new. Ever since the issue has emerged in the early nineteenth century, upto late twentieth century the issue was a topic discussed exclusively within the scientific society. Climate change refers to significant changes in global temperature, precipitation, wind patterns and other measures of climate that occur over several decades or longer ${ }^{[1]}$. Climate change is a reality, and it has already started assuming an ugly look which warrants immediate attention by the rank and file of the country ${ }^{[2]}$. The seas are rising, the foods we eat and take for granted are threatened. Ocean acidification is increasing. Ecosystems are changing and for some, that could spell the end of certain regions the way we have known them. And while some are adapting, for others, it's not that easy. Scientists have warned that India is one of the more vulnerable and risk prone nations in the world, not immune to the impact of climate change ${ }^{[3]}$. 


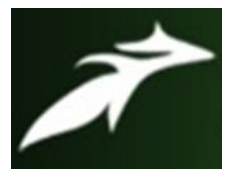

Gottipalli Jaya Pravallika et al, International Journal of Advances in Agricultural Science and Technology, Vol.7 Issue.12, December-2020, pg. 15-20

ISSN: 2348-1358

Impact Factor: 6.057

NAAS Rating: 3.77

Climate change and agriculture are interrelated process. Among various factors that are being affected by climate change, agriculture is the prominent one. Globally, climate change is the most serious environmental threat that adversely affects agricultural productivity. There are many developing nations where agriculture is the main occupation for most of the population. The IPCC third assessment report 2001 concluded that, the poorest countries would be hardest hit with reductions in crop yields in most tropical and sub- tropical regions due to decreased water availability and new or changed insect pest incidence. When agriculture is being affected due to climate change, Farmers' are obviously affected as they depend on agriculture for their livelihood. Climate change is destroying the lives of the farmers so it is necessary for them to have complete knowledge about it.

Perception is the way in which something is regarded, understood or interpreted. Perception of humans varies from person to person. Not all interpret the same way. Perception refers to the opinion of farmers. Farmers' perception about climate change, therefore, strongly effects how they deal with climate induced risks and uncertainties and undertake specific measures by coping strategies to mitigate the adverse impact of climate change on agriculture ${ }^{[4]}$. Though farmers' are observing and perceiving the changes in the climate they particularly have no idea about what is it that is leading to climate change or why is the climate being deteriorating or why is it affecting everything that exists on the earth. And the perception of the farmers is very different from the current scenario of the climate change.

\section{METHODOLOGY}

The present study was conducted in Chevella block of Rangareddy District of Telangana and has been purposively selected in 2019-20. As it is closely located to the urban areas. Six villages namely chevella, palgutta, Rammanaguda, Kesaram, Damaragidha, Aloor were randomly selected. A well-structured interview schedule with relevant questions was prepared and pretested for the study. The sample population of 120 respondents was selected through random sampling method from the 6 villages. Relevant questions about climate change were asked through personal interview method and the responses were recorded.

Statistical method is the scientific method of judging collective natural or social phenomena from the results obtained by the analysis of enumerated or collected estimates. Responses were recorded on 5- point continuum scale viz. strongly agree, agree, undecided, disagree, strongly disagree by assigning scores 5, 4, 3, $2 \& 1$, respectively. Further the overall perception of farmers on climate change was determined and the respondents were categorized as low (2129score), medium (29-36score), and high (37-41 score). 


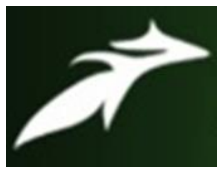

Gottipalli Jaya Pravallika et al, International Journal of Advances in Agricultural Science and Technology, Vol.7 Issue.12, December-2020, pg. 15-20

ISSN: 2348-1358

Impact Factor: 6.057

NAAS Rating: 3.77

\section{RESULTS AND DISCUSSION}

Perception of farmers' on climate change.

Table 1 Distribution of farmers based on their perception on climate change

\begin{tabular}{|c|c|c|c|c|c|c|c|c|c|c|c|}
\hline \multirow[t]{2}{*}{ S.No. } & \multirow[t]{2}{*}{ Statements } & \multicolumn{2}{|c|}{$\begin{array}{l}\text { Strongly } \\
\text { agree (SA) }\end{array}$} & \multicolumn{2}{|c|}{ Agree (A) } & \multicolumn{2}{|c|}{$\begin{array}{l}\text { Undecided } \\
\text { (UD) }\end{array}$} & \multicolumn{2}{|c|}{ Disagree(D) } & \multicolumn{2}{|c|}{$\begin{array}{l}\text { Strongly } \\
\text { disagree } \\
\text { (SD) }\end{array}$} \\
\hline & & $\mathbf{F}$ & $\mathbf{P}$ & $\mathbf{F}$ & $\mathbf{P}$ & F & $\mathbf{P}$ & $\mathbf{F}$ & $\mathbf{P}$ & $\mathbf{F}$ & $\mathbf{P}$ \\
\hline 1. & $\begin{array}{l}\text { Do you think the } \\
\text { temperatures } \\
\text { have increased } \\
\text { from past years }\end{array}$ & 49 & 40.83 & 47 & 39.16 & 16 & 13.34 & 8 & 6.67 & - & - \\
\hline 2. & $\begin{array}{l}\text { Do you think the } \\
\text { seasonal } \\
\text { monsoons are } \\
\text { not on time }\end{array}$ & 39 & 32.5 & 52 & 43.33 & 19 & 15.83 & 8 & 6.67 & 2 & 1.67 \\
\hline 3. & $\begin{array}{lr}\text { Do you } & \text { think } \\
\text { amount } & \text { of } \\
\text { rainfall } & \text { is } \\
\text { decreasing } & \end{array}$ & 18 & 15 & 43 & 35.83 & 41 & 34.16 & 16 & 13.34 & 2 & 1.67 \\
\hline 4. & $\begin{array}{l}\text { Do you think } \\
\text { amount of rain } \\
\text { fall is increasing }\end{array}$ & 20 & 16.67 & 21 & 17.5 & 45 & 37.5 & 26 & 21.67 & 8 & 6.67 \\
\hline 5. & $\begin{array}{ll}\text { Do you } & \text { think } \\
\text { there are } & \text { more } \\
\text { dry spells } & \end{array}$ & 5 & 4.16 & 43 & 35.83 & 55 & 45.83 & 15 & 12.5 & 2 & 1.67 \\
\hline 6. & $\begin{array}{l}\text { Do you think } \\
\text { winter } \\
\text { temperature is } \\
\text { increasing }\end{array}$ & 26 & 21.67 & 52 & 43.33 & 24 & 20 & 15 & 12.5 & 3 & 2.5 \\
\hline 7. & $\begin{array}{l}\text { Do you think } \\
\text { summer } \\
\text { temperatures are } \\
\text { increasing }\end{array}$ & 46 & 38.33 & 50 & 41.67 & 18 & 15 & 6 & 5 & - & - \\
\hline
\end{tabular}




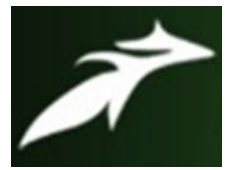

Gottipalli Jaya Pravallika et al, International Journal of Advances in Agricultural Science and Technology, Vol.7 Issue.12, December-2020, pg. 15-20

ISSN: 2348-1358

Impact Factor: 6.057

NAAS Rating: 3.77

\begin{tabular}{|l|l|l|l|l|l|l|l|l|l|l|l|}
\hline 8. & $\begin{array}{l}\text { Do you feel the } \\
\text { rise in humidity }\end{array}$ & 4 & 3.33 & 44 & 36.67 & 46 & 38.33 & 16 & 13.33 & 10 & 8.33 \\
\hline 9. & $\begin{array}{l}\text { Do you think } \\
\text { intensity of fog } \\
\text { has increased }\end{array}$ & 26 & 21.67 & 62 & 51.67 & 22 & 18.34 & 9 & 7.5 & 1 & 0.83 \\
\hline
\end{tabular}

Majority of respondents $(40.83 \%)$ strongly agreed that temperature has increased from past years, $43.33 \%$ agreed that seasonal monsoons are not on time, 35.83\% respondents agreed that amount of rainfall is decreasing, $37.5 \%$ respondents can't decide that amount of rainfall is increasing, 45.83\% respondents can't decide whether the dry spells are more or not, 43.33\% respondents agreed that winter temperatures were increasing, $41.67 \%$ agreed that summer temperatures were increasing, 38.33\% respondents can't decide whether humidity is increasing or not and $51.67 \%$ respondents agreed that intensity of fog has increased.

Table 2 distribution of respondents based on their level of perception

\begin{tabular}{|l|l|c|c|}
\hline & Perception & Frequency & Percentage \\
\hline 1. & Low (21-28) & 18 & 15 \\
\hline 2. & Medium (29-36) & 84 & 70 \\
\hline 3. & High (37-41) & 18 & 15 \\
\hline & Total & 120 & 100 \\
\hline
\end{tabular}

From the above table, it is evident that majority of respondents had $70 \%$ i.e. medium level of perception on climate change followed by high and low level of perception i.e. $15 \%$. 


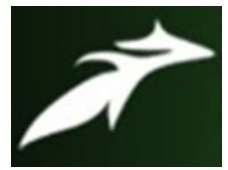

Gottipalli Jaya Pravallika et al, International Journal of Advances in Agricultural Science and Technology, Vol.7 Issue.12, December-2020, pg. 15-20

ISSN: 2348-1358

Impact Factor: 6.057

NAAS Rating: 3.77

Table 3 Distribution of respondents according to their perception on cause of climate change

When farmers' were asked about their perception on what is it that's resulting in climate change that's affecting agriculture their responses are as below.

\begin{tabular}{|l|l|c|c|}
\hline S.No. & Perception & Frequency & Percentage \\
\hline 1. & Disobedience to God & 64 & 53.33 \\
\hline 2. & Pollution & 31 & 25.84 \\
\hline 3. & Deforestation & 25 & 20.83 \\
\hline & Total & 120 & 100 \\
\hline
\end{tabular}

From the above table it is revealed that 53.33 per cent farmers perceived climate change to be a result of people's disobedience to god, in their point of view, god was punishing humans for their sins. And 25.84 percent farmers perceived it to be due to pollution. And 20.83 percent farmers perceived as Deforestation. From the study it is evident that farmers' perception is a lot more varied than the scientific observations.

\section{CONCLUSION}

Findings of present study revealed that farmers' perception level on climate change is medium level and their perception on cause or reason of what is it that's causing climate change, majority of them responded that their disobedience to God was the main reason. That their God was punishing them for their sins. The study highlighted that, though farmers' were noticing the changes in their surroundings about climate change, they had their own beliefs and perceived in their own convenient way. 


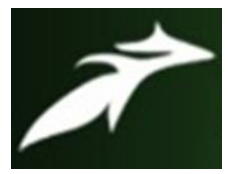

Gottipalli Jaya Pravallika et al, International Journal of Advances in Agricultural Science and Technology,

Vol.7 Issue.12, December-2020, pg. 15-20

ISSN: 2348-1358

Impact Factor: 6.057

NAAS Rating: 3.77

\section{REFERENCES}

IFRC, 2005 International Federation of Red Cross and Red Crescent Societies. www.ifrc.org

IPCC, 2001: Climate Change 2001: Synthesis report. A contribution of working groups I, II, and III to the Third Assessment Report of the Intergovernmental Panel on Climate Change. Cambridge university press, Cambridge, United Kingdom, and New York, NY, USA, 398 pp.

Rahman, M. I: Climate Change: a theoretical review, Interdisciplinary Description of Complex System Journal. 11(1), 1-13, 2013.

${ }^{[3]}$ Parsuraman, S., \& Unnikrishnan, P.V. (2000) Indian Disasters Report, Oxford University Press: New Delhi.

${ }^{[4]}$ Raghuvanshi, Rupan, Ansari MA. A study of farmers' awareness about climate change and adaptation practices in India. International Journal of Applied Agriculture Research.

2017; 3(6):154-160.

${ }^{[2]}$ Shukla, P.R. (2003) Climate change in India: Vulnerability Assessment and Adaptation, Hyderabad University Press. Hyderabad.

${ }^{[1]}$ UC Davis, University Of California.Climatechange.ucdavis.edu 